\title{
Effects of grazing animals on the plant availability of sulphur fertilisers in grazed pastures
}

K.M. GOH1 and M.L. NGUYEN ${ }^{1,2}$ 'Department of Soil Science, Lincoln University, Canterbury 'Present address: MAF Technology, South Central, Lincoln

\begin{abstract}
Most field trials conducted in New Zealand for assessing pasture plant sulphur (S) requirements use the mowing and clipping return technique without the inclusion of grazing animals. A rotational grazing experiment and a field plot trial were conducted on a Templeton silt loam soil (Udic Ustochrept) in Canterbury using radioactive ${ }^{35} \mathrm{~S}$-labelled fertilisers to examine the effects of grazed sheep on the plant availability and cycling of applied $S$ fertilisers. An additional plot trial was conducted to determine leaching losses of ${ }^{35} \mathrm{~S}$-labelled urine applied to pastures. The results obtained showed that maximum ${ }^{35} \mathrm{~S}$ concentration in pastures treated with elemental $\mathrm{S}$ occurred 3 months earlier in the grazed trials compared with that of ungrazed plots. This increased herbage $S$ was also reflected in the wool ${ }^{35} \mathrm{~S}$ of ewes which grazed the pastures. In addition, the amount of residual elemental $\mathrm{S}$ remaining in the soil after 3 months of its application was- significantly lower in grazed than in ungrazed pastures. These results suggest that grazing animals enhanced the plant availability of elemental S probably because of the effects of animal trampling and the return of animal faeces. It was also found that about $36-44 \%$ of the applied ${ }^{35} \mathrm{~S}$ fertilisers and up to $68 \%$ of the applied urinary ${ }^{35} \mathrm{~S}$ were not recovered in the soil within one growing season in the field. Thus grazing animals enhanced not only the availability of elemental S, but were also responsible for substantial losses of $\mathrm{S}$ from pastures through animal excreta. The present data suggest that field trial results obtained from mowing plot trials without the inclusion of grazing animals are unlikely to assess adequately the plant availability of elemental S.
\end{abstract}

Keywords sulphur, nutrient cycling, urine, sulphur leaching, recovery, fertiliser, elemental sulphur, oxidation, sheep grazing, mowing, grazing

\section{Introduction}

Sulphur (S) fertiliser requirements of grazed pastures are known to be affected by the extent and rate of $S$ cycling in the soil-plant-animal system (Till et al. 1987). The effects of grazing animals in affecting pasture $S$ requirements have been recognised in the MAF S model (Sinclair \& Saunders 1984), but the quantitative data available to account for these effects are limited (Sinclair 1983); and there are no published data on the effects of grazing animals on the plant availability of elemental $S$, which is becoming an important $\mathrm{S}$ fertiliser in the current trend of using high-analysis phosphatic fertilisers with low $\mathrm{S}$ content.

The main objective of the present study was to, investigate the impact of grazing animals on the plant availability of fertilisers containing sulphate (gypsum) and elemental $\mathrm{S}$ in intensively grazed irrigated pastures in Canterbury.

\section{Methods}

A rotational sheep grazing experiment (annual stocking rate 25 stock units/ha- -with- an annual pasture utilization of 90\%) and a field plot trial were conducted at the Templeton Research Station (MAF Technology, Lincoln) on a Templeton silt loam soil (Udic Ustochrept). The site was on a well-improved irrigated pasture which has been regularly topdressed with superphosphate fertiliser for 15 years.

On each of these trials, gypsum and elemental $\mathrm{S}$, both labelled with ${ }^{35} \mathrm{~S}$ radioactive tracer $(3.97 \mathrm{~m} \mathrm{Ci} / \mathrm{g}$ S) applied at $25 \mathrm{~kg} \mathrm{~S} / \mathrm{ha}$ were evaluated together with the control (zero $\mathrm{S}$ fertiliser) in a randomised complete block design with 4 replicates per treatment. Irrigation water was applied under a roster system with a minimum return period of 21 days. Soil herbage samples were collected periodically from the grazed and ungrazed field plots throughout the year. Wool production was monitored at 3-monthly intervals. Soil, herbage and wool samples were analysed for $\mathrm{S}$ and radioactive ${ }^{35} \mathrm{~S}$. The amount of residual elemental $\mathrm{S}$ remaining in the field soil throughout the year was also determined. 


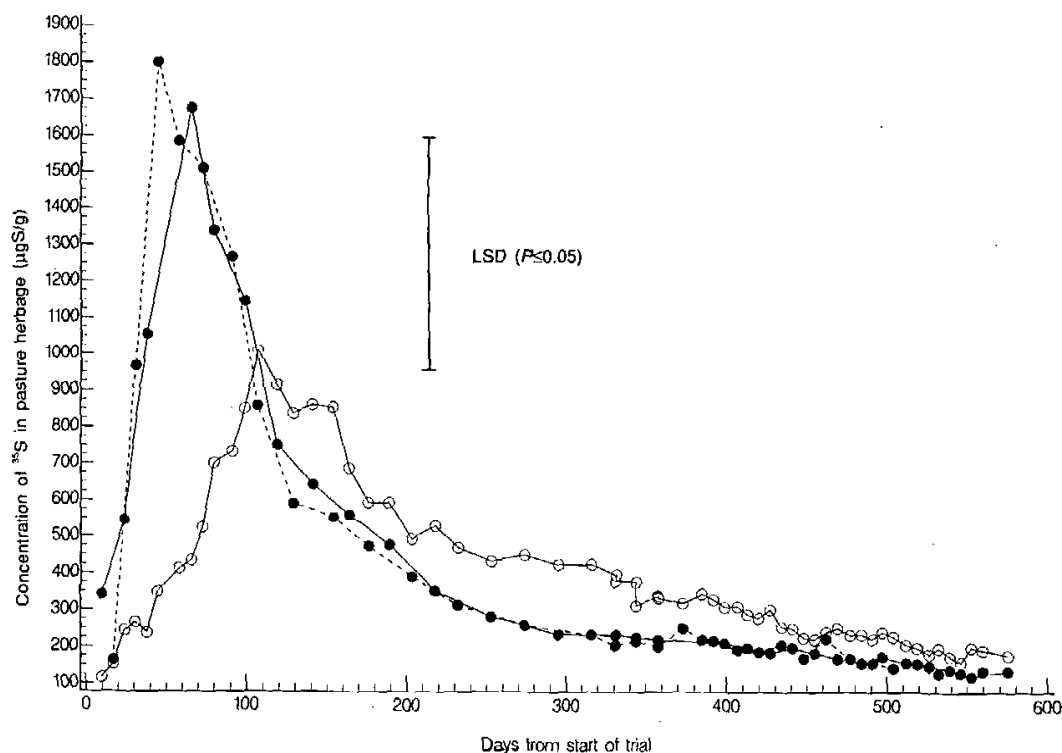

Figure 1 Concentrations of ${ }^{35} \mathrm{~S}$ in pasture herbage from ungrazed plot trial $(\mathrm{O}-\mathrm{O})$ and from grazed pastures collected before ( - - ) and after (-_ ) each grazing in treatments which have received ${ }^{35} \mathrm{~S}$-labelled elemental sulphur.

An additional field experiment was conducted to determine the extent of losses of sheep urinary $\mathbf{S}$ under field conditions by applying $1800 \mathrm{ml}$ of ${ }^{33}$ S-labelled urine $(1300 \mu \mathrm{g} \mathrm{S} / \mathrm{ml}$ and $250 \mu \mathrm{Ci} / \mathrm{gS})$ to field plots $(60 \mathrm{~cm} \times 60 \mathrm{~cm})$. This rate is equivalent to the reported rate of $150 \mathrm{ml}$ of urine deposited on a urine patch of $0.030 \mathrm{~m}^{2}$ (Quin 1977). Irrigation was applied to the plots whenever the available soil moisture in the top $45 \mathrm{~cm}$ soil depth was at less than $25 \%$. Soil, herbage and plant roots were collected periodically and analysed for $\mathrm{S}$ and ${ }^{\text {is }} \mathrm{S}$.

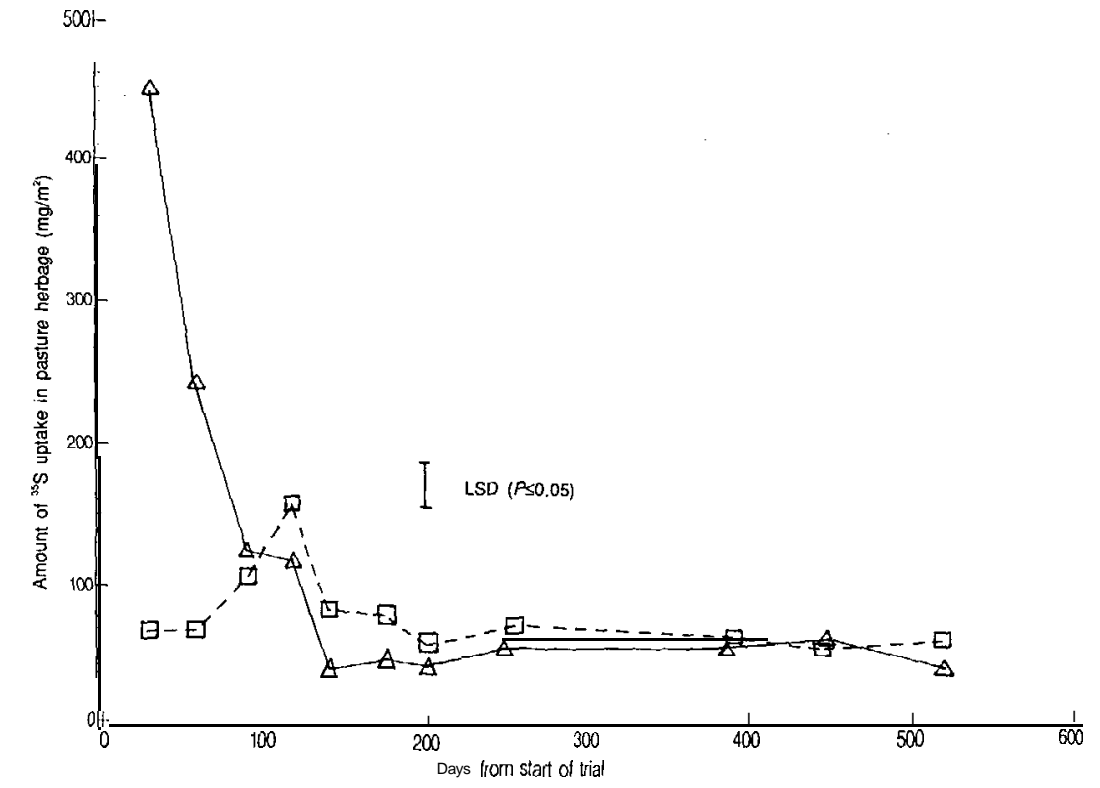

Figure 2 Amount of ${ }^{35} \mathrm{~S}$ uptake in pasture herbage from ungrazed plot trial receiving gypsum (A) and elemental sulphur (ㅁ).

\section{Results and discussion}

Plant sulphur in grazed and ungrazed plots

Maximum ${ }^{35} \mathrm{~S}$ concentration of herbage occurred 3 months earlier in grazed plots than in ungrazed plots (Figure 1) after the application of ${ }^{35}$ S-labelled elemental S fertiliser. In addition, in ungrazed plots the amount of ${ }^{35} \mathrm{~S}$ uptake by plant herbage was lower in treatments receiving elemental $\mathbf{S}$ than gypsum (Figure 2), up to 3 months after the start of the trial, whereas no such difference was found in the grazing 


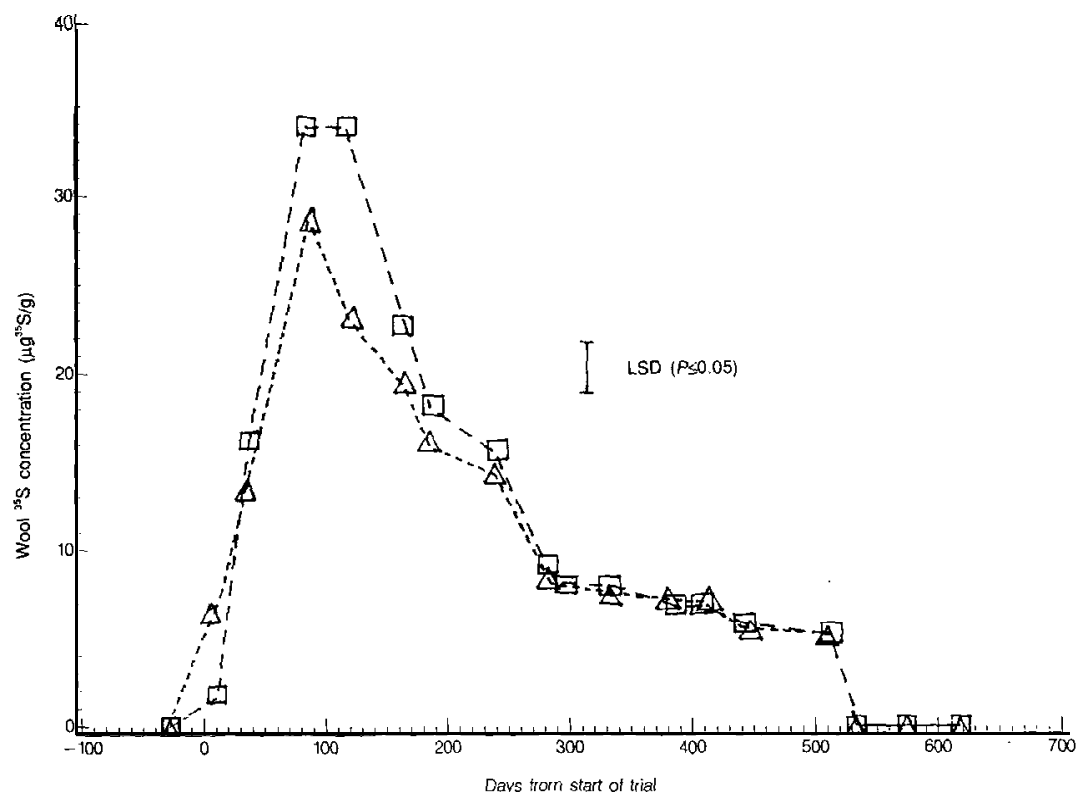

Figure 3 Concentration of ${ }^{35} \mathrm{~S}$ in wool from sheep grazed pastures treated with gypsum (A) and elemental sulphur (Cl),

trials (results not presented). These results suggest that the presence of grazed animals enhanced plant uptake of elemental $S$.

Wool sulphur

The increase in plant ${ }^{35} \mathrm{~S}$ concentration (Figure 1) was reflected in wool ${ }^{35} \mathrm{~S}$ concentration (Figure 3) of ewes that grazed the pasture. Except for the period between 80 and 150 days after ${ }^{35} \mathrm{~S}$ fertiliser application, the incorporation of ${ }^{35} \mathrm{~S}$ into wool was similar in grazed treatments receiving elemental $\mathrm{S}$ and gypsum. This suggests that grazing animals also enhanced wool $\mathrm{S}$ incorporation from elemental $\mathrm{S}$ through the trampling effect of grazing animals or the return of animal excreta on the oxidation of elemental $S$ to the plant-available soil sulphate form for plant uptake. These effects are likely to occur in grazed pastures, since Burns (1967) in his review has

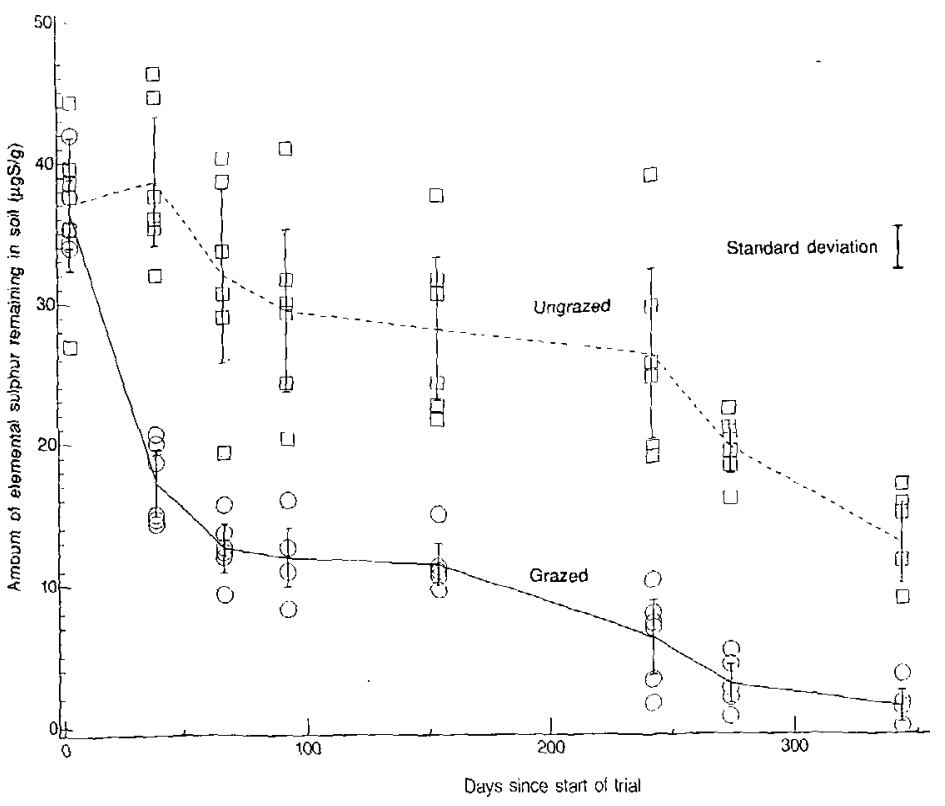

Figure 4 Amount of residual elemental sulphur fertiliser remaining in soils after its application to grazed $(O)$ and ungrazed (D) plots. 
Table $1{ }^{\text {ss }} \mathrm{S}$ recovery $(\mathbf{\%})$ in soil, root and herbage of pasture plants after different periods of fertiliser application in the grazed trial.

\begin{tabular}{|c|c|c|c|c|c|c|c|c|}
\hline \multirow{3}{*}{$\begin{array}{l}\text { Months after } \\
{ }^{35} \text { S application }\end{array}$} & \multicolumn{8}{|c|}{${ }^{35} \mathrm{~S}$ recovery $(\%)$} \\
\hline & \multicolumn{4}{|c|}{ Gypsum } & \multicolumn{4}{|c|}{ Elemental sulphur } \\
\hline & Soil & Root & Herbage & Total & Soil & Root & Herbage & Total \\
\hline 1 & 73.2 & 4.1 & 14. 3 & 91.6 & 89.2 & 4.6 & 12.6 & 106.4 \\
\hline 3 & 58.7 & $\mathrm{NA}$ & 3.8 & 62.5 & 66.6 & $\mathrm{NA}$ & 9.7 & 76.3 \\
\hline 5 & 43.1 & 2.5 & 1.5 & 47.1 & 48.6 & 3.2 & 2.2 & 54.0 \\
\hline 8 & 33.8 & 2.7 & 1.1 & 37.6 & 36.4 & 2.4 & 2.1 & 40.9 \\
\hline 10 & 28.4 & 2.3 & 0.7 & 31.4 & 29.8 & 2.2 & 0.4 & 32.4 \\
\hline \multicolumn{9}{|l|}{$\operatorname{LSD}(\mathrm{P}<0.05)$} \\
\hline Treatment & 2.4 & 0.4 & 0.3 & 0.5 & & & & \\
\hline Sampling months & 3.6 & 0.5 & OS & 0.5 & & & & \\
\hline Treatment $\mathrm{x}$ sampling & 5.5 & 0.8 & 0.9 & 0.9 & & & & \\
\hline
\end{tabular}

$\mathrm{NA}=$ not applicable

shown that the mixing of elemental $\mathbf{S}$ with soil provided higher elemental $\mathbf{S}$ oxidation than a surface application of elemental S. In addition, the returns of animal excreta have been found to modify the microbial population, soil $\mathrm{pH}$ and soil nutrients (Ndayegamiye \& Coyte 1989), and elemental S oxidation has been shown to be influenced by soil $\mathrm{pH}$ and soil nutrients (Bloomfield 1967; Wainwright 1984).

\section{Residual soil elemental sulphur in grazed and ungrazed plots}

A significantly lower amount of residual elemental $\mathrm{S}$ remained in the soil $(\mathrm{O}-75 \mathrm{~mm})$ of grazed than of ungrazed plots (Figure 4). This difference was most evident in the 3 months after elemental $\mathbf{S}$ application, thus showing that the applied elemental $\mathbf{S}$ was more rapidly oxidised in the presence of grazed animals. Thus the presumed slow-release elemental $\mathbf{S}$ was as effective as the rapid-release gypsum in the grazed trial. This is probably due to the effects of the return of animal faeces and animal trampling thereby inproving contact between elemental $\mathbf{S}$ particles and the soil. Both these effects could have led to enhanced microbial oxidation of elemental $\mathbf{S}$ in the soil of grazed pastures.

\section{Recovery of ${ }^{35} \mathbf{S}$}

After one growing season (10 months), only 56 to $64 \%$ of the applied $S$ fertiliser were recovered in the soil, root and herbage of pasture plants in the grazed trial (Table 1). This suggests that a substantial amount (about 3644\%) of the applied fertilisers was lost in the grazed plots by leaching or excreta transfers to animal campsites or both.

The above data support recent results reported in North Island hill country (Lambert et al. 1988; Saggar et al. 1990) and in the long-term Winchmore trial (Nguyen \& Goh 1990) which showed that regular annual applications of superphosphate fertiliser to pastures did not lead to a continued increase in the accumulation of soil organic $\mathrm{S}$ in low sulphateretentive soils. A substantial amount to the applied $\mathbf{S}$ was unaccounted for and was postulated to have been lost through leaching. Thus applications of $\mathbf{S}$ fertilisers above the required maintenance level was unwise.

There was no significant difference in ${ }^{3 s} \mathrm{~S}$ recovery between elemental $\mathbf{S}$ and gypsum at 10 months after fertiliser application (Table 1), further supporting the observation that both these fertilisers behaved similarly in the grazed trial.

\section{Losses of urinary ${ }^{38} \mathbf{S}$}

Only about $32 \%$ of the applied urinary ${ }^{35} \mathrm{~S}$ was recovered in the soil, root and pasture plant herbage at 270 days after urine application (Table 2). Thus a substantial amount (about 68\%) of urinary $\mathbf{S}$ was subjected to leaching losses in the low sulphateretentive Templeton silt loam soil.

\section{Conclusions}

Results from the present study show that grazing animals play an important role in the cycling of $\mathrm{S}$ in grazed pastures. They influenced significantly the availability of $\mathbf{S}$ from fertilisers applied to pasture plants and also losses of fertiliser $\mathbf{S}$ from the soilplant-animal systems.

The exclusion of grazing animals in field trials is therefore unlikely to assess adequately the availability of elemental S to pasture plants. Future research aims at determining the plant availability of elemental S-based fertilisers should be conducted in the presence of grazing animals since both animal trampling and the return of animal excreta may modify the oxidation rate of elemental S. Any

Table $2{ }^{3 s} S$ recovery $(\%)$ in soil, root and herbage of pasture plants at different sampling periods (days) after application of ${ }^{35}$ S-labelled urine.

\begin{tabular}{|c|c|c|c|c|}
\hline \multirow{2}{*}{$\begin{array}{l}\text { Components } \\
\text { analysed }\end{array}$} & \multicolumn{3}{|c|}{$\begin{array}{c}{ }^{3 s} S \text { recovery }(\%) \text { at different } \\
\text { periods } \text { (days) }\end{array}$} & t sampling \\
\hline & 48 & 75 & 215 & 270 \\
\hline $\begin{array}{l}\text { Soil } \\
\text { Roots } \\
\text { Herbage }\end{array}$ & $\begin{array}{r}68.2 \pm 4.1 \\
3.4 \pm 0.9 \\
2.9 \pm 0.5\end{array}$ & $\begin{array}{c}28.3 \pm 2.4 \\
3.7 \mathrm{k0} .8 \\
2.6 \pm 1.1\end{array}$ & $\begin{array}{l}\text { NA } \\
\text { NA } \\
0.3 \pm 0.1\end{array}$ & $\begin{array}{r}22.6 \pm 3.5 \\
2.7 \pm 0.5 \\
1.0 \pm 0.1\end{array}$ \\
\hline
\end{tabular}


variation in this oxidation rate may subsequently affect plant $S$ uptake and hence the overall $S$ cycling in grazed pastures. Applications of $S$ fertilisers above the maintenance level are likely to lead to substantial losses of S from the soil-plant-animal systems in low sulphate-retaining soils,

\section{ACKNOWLEDGEMENTS}

MAF Technology for granting study leave to M.L. Nguyen Mrs M. Forbes and Mr R. Orchard for their technical assistance; MAF Technology, Lincoln University Research Committee and the Vernon Willey Trust for providing funding.

\section{REFERENCES}

Bloomfield, C. 1967. Effect of some phosphate fertilisers on the oxidation of elemental sulphur in soil. Soil science 103: 219-223.

Burns, G.R. 1967. Oxidation of sulphur in soils. The Sulphur Institute Technical Bulletin 13. The Sulphur Institute, Washington.

Lambert, M.G.; Clark, D.A.; Costall, D.A.; Budding, P.J. 1988. Phosphorus and sulphur accumulation after long-term superphosphate application to grazed hill country. pp. 95-100. In Proceedings of the Workshop, Towards the More Efficient Use of Soil and Fertiliser Sulphur, Massey University, Palmerston North, 17-18 February, 1988. White, R.E.; Currie, L.D. (eds). Ferfiliser and Lime Research Centre, Occasional Report No. 2. Massey University, Palmerston North, New Zealand. 318p.

Ndayegamiye, A.; Cote, D. 1989. Effect of long-term pig slurry and solid cattle manure application on soil chemical and biological properties. Canadian journal of soil science 69: 39-47.
Nguyen, M.L.; Goh, K.M. 1990. Accumulation of soil sulphur fractions in grazed pastures receiving longterm superphosphate applications. NZ journal of agricultural research 33: 111-I 28.

Quin, B.F. 1977. The fate of sheep urine - nitrogen on surface - irrigated pasture in Canterbury. In Proceedings of Workshop on Nitrogen Transformations in the Soil-Pasture System. Ed. W.M.H. Saunders. NZ Soil News 25(4): 140-143.

Saggar, S.; Mackay, A.D.; Hedley, M.J.; Lambert, M.G.; Clark, D.A. 1990. A nutrient transfer model to explain the fate of phosphorus and sulphur in a grazed hillcountry pasture. Agriculture, ecosystems and environment 39: In Press.

Sinclair, A.G. 1983. Problems in modelling sulphur requirements in New Zealand pastures. pp. 106-1 17. In Proceedings of the Technical Workshop on Sulphur in New Zealand Agriculture Massey University, Palmerston North, 23 and 24 May 1983. Gregg, P.E.H.; Syers, J.K. (eds). Department of Soil Science Occasional Report No. 4. Massey University, Palmerston North, New Zealand. 198 p.

Sinclair, A.G.; Saunders, W.M.H. 1984. Pasture maintenance, sulphur. pp. 15-17. In Fertiliser Recommendations for Pastures and Crops in New Zealand. Second Revised Edition. New Zealand Ministry of Agriculture and Fisheries. Agricultural Research and Advisory Services Divisions, Wellington, New Zealand.

Till, A.R.; May, P.F.; Saunders, W.M.H.; Sinclair, A.G. 1987. Plant nutrient sulphur requirements: Oceania pp. 63-73. In Sulphur 87. World Regional Requirements. Plant nutrient sulphur. Co-sponsored by The Sulphur Institute and The British Sulphur Corporation.

Wainwright, M. 1984. Sulphur oxidation in soils. Advances in agronomy 37: 349-396. 